Ethnobotanical features of Ula (Muğla/Turkey) district

\author{
Serdar KINCAL ${ }^{1}$, Olcay CEYLAN *2, Güven GÖRK ${ }^{2}$ \\ ORCID: 0000-0002-7598-1240; 0000-0002-4435-8405; 0000-0001-5766-691X
}

\author{
${ }^{1}$ Muğla Sitkı Koçman University, Graduate School of Natural and Applied Sciences, 48000 Muğla, Turkey \\ ${ }^{2}$ Muğla Sıtkı Koçman University, Faculty of Science, Department of Biology, 48000 Muğla, Turkey
}

\begin{abstract}
The ethnobotany field study was conducted between the years 2016-2018 in the central and affiliated neighborhoods of Muğla Province, Ula District and view interviewed with people from different age and social categories. In Ula, our study area, 123 plant species belonging to 53 families were recorded. 70 of these plants have natural distribution in the region and 45 of them are grown by the public. Plants used in the region were mostly used for medical and food purposes. 71 plant species were found medicinal, 69 plant species were used for food and spice purposes. In the district 28 plants are used for burning, broom and goods, 2 plant species are used for cleaning and maintenance purposes. Among the 53 naturally growing families, Rosaceae are represented by 12 species, Lamiaceae with 10 species and the most taxa. Originum onites L. and Lavandula stoechas L. belonging to the family Rosaceae Cydonia oblonga Mill., Pyrus communis L. and Lamiaceae were found to be among the plants widely used in the region. In terms of the number of plant species they contain, these families are followed by 9 species of Fabaceae and 7 species of Poaceae. Hypericum perforatum L. var. perforatum from Hypericaceae, Pinus nigra Arn. from Pinaceae, Platanus orientalis L., Olea europaea L. from Oleaceae and Tilia rubra L. from Tiliaceae, are among the plants widely used in the region.
\end{abstract}

Keywords: Muğla, ethnobotany, Ula, Turkey

\title{
Ula (Muğla) ilçesinin etnobotanik özellikleri
}

\section{Özet}

Muğla İli Ula İlçesi Merkez ve bağlı mahallelerinde 2016-2018 yılları arasında yaptığımız etnobotanik alan çalışmamızda farklı yaş ve sosyal kategorilerden kişilerle görüşülmüştür. Çalışma alanımız olan Ula'da 53 familyaya ait 123 bitki türü kaydedilmiştir. Bu bitkilerden 70 tanesi yörede doğal yayılışa sahip olup bu bitkilerin 45 tanesi halk tarafından yetiştirilmektedir. Yörede kullanılan bitkilerin çoğunlukla tıbbi ve gıda amaçlı olarak kullanıldığ görülmüştür.71 bitki türünün tıbbi, 69 bitki türünün gıda ve baharat amaçlı kullanımları saptanmıştır. Bölgede 28 bitki yakacak, süpürge ve eşya yapımında, 2 bitki türü temizlik ve bakım amaçlı kullanılmaktadır. Doğal olarak yetişen 53 familya içerisinden Rosaceae 12 tür, Lamiaceae 10 türle en fazla taksonla temsil edilen familyalardır. Rosaceae familyasına ait Cydonia oblonga Mill., Pyrus communis L.ve Lamiaceae familyasına ait Origanum onites L. ve Lavandula stoechas L.'nın yörede yaygın olarak kullanılan bitkiler arasında olduğu tespit edilmiştir. İçerdiği bitki türü sayısı bakımından bu familyaları 9 türle Fabaceae, 7 türle Poaceae izlemektir. Ayrıca Hypericaceae'den Hypericum perforatum L. var. perforatum, Pinaceae'den Pinus nigra Arn., Platanaceae'den Platanus orientalis L., Oleaceae'den Olea europaea L., Tiliaceae'den Tilia rubra L. yörede yaygın olarak kullanılan bitkiler arasında yer almaktadır.

Anahtar kelimeler: Muğla, etnobotanik, Ula, Türkiye

\footnotetext{
${ }^{*}$ Corresponding author / Haberleşmeden sorumlu yazar: Tel.: +905334108366; Fax.: +902522111472; E-mail: oceylan@ mu.edu.tr

(c) Copyright 2021 by Biological Diversity and Conservation Geliş tarihi: 09.04.2020; Yayın tarihi: 15.04.2021 BioDiCon. 905-0420
} 


\section{Giriş}

Bitkilerin tedavi amaçlı kullanılmasının M.Ö. 3000 yıllarına dayandığı ve birçok ünlü Türk bilim adamının (İbn-i Sina, Biruni, Davud Al-Antaki, Ebu Reyhan, İbn Baytar) bitkisel droglarla uğraştığ bilinmektedir [1]. Mezopotamya uygarlığı döneminde bitkisel drog miktarı 250 civarında, Grekliler döneminde drog miktarı 600'e kadar çıkmıştır. Arap-Fars döneminde bu miktar 4000'e kadar yükselmiştir. 19. yüzyıl başlarında bilinen tıbbi bitki sayısı 13000 sayısına ulaşmıştır [2].

Tedavi amacıyla kullanılan yaklaşık 20.000 bitkinin 600 kadarı Türkiye'de doğal olarak yetiştirilmektedir [3]. 20. yüzyılın başlarında teknolojik gelişmelerin getirdiği yenilikler, sosyal ve politik değişimler bitkilerin ilaç olarak kullanımının hızla azalmasına neden olmuştur. Aynı zamanda ilaç sanayinde sentetik ilaçların üretilmesi de bunda etkili olmuştur [4]. Günümüzde insanlar tedavi için laboratuvarda üretilen ilaçlar yerine doğal ilaçları tercih etmektedirler. Bunda sentetik ilaçların çok ciddi yan etkilerinin olmasının etkisi büyüktür. Almanya'da 500 farklı bitkiden bitkisel ilaç üretimi için yararlanılmakta, Almanların \%52'si önemsiz hastalıkların ilk tedavisi için bitkisel ilaçları kullanmaktadır [5].

Nüfus ve sanayileşme ile insanların doğal kaynaklara olan ihtiyacı gün geçtikçe artmakta ve bu kaynaklardan faydalanma yollarını araştırmaya sevk etmektedir. Türkiye doğal kaynaklarda olduğu gibi bitkisel kaynaklar bakımından da zengin bir ülke konumundadır [6].

Ülkemiz florasına ait yapılmış çalışmalarda ülkemizde yaklaşık 11000 takson bulunmakta ve bu taksonların yaklaşık 500 tanesi tedavi amaçlı kullanılmaktadır [7]. Bitkilerin kullanım alanları çeşitlilik göstermekte olmasına rağmen en fazla kullanımın gıda-tedavi amaçlı olduğu görülmektedir. Bitkilerin başka kullanım alanları içinde iç ve dış mekân süslemesi, kök, çiçek gibi organlarından boyar madde eldesi, reçinesinin kâğıt ve yapıştırıcı üretiminde, çiçek ve uçucu yağından koku eldesi, uçucu yağının psikolojik ve fiziksel rahatlamada, kozmetikte, gıda takviyesi olarak, çit, merdiven, kaşık, yaba, sürgü gibi alet yapımında kullanılması sayılabilir.

Muğla ve yöresi bitki çeşitliliği ve sahip olduğu endemik bitkiler bakımından oldukça zengindir. Muğla ili sinırları içerisinde 1219 takson, 1164 tür bulunmakta olup bu türlerin 238 tanesi endemiktir [6]. Ülkemizde ise son yıllarda etnobotanik çalışmalara verilen önem artmış ve kaybolmaya yüz tutmuş olan bu değerlerimizi ortaya çıkarmak için birçok çalışma yapılmıştır [8-13]. Özellikle Muğla ilinde [14-19] birçok etnobotanik çalışmaların yapıldığı görülmektedir. Ula ilçesinin de çalışılmasıyla Muğla ilinin etnobotanik alandaki çalışmalarının büyük ölçüde tamamlanması çalışma amacımızı oluşturmaktadır.

\section{1 Çalışma Alanı}

Ula, Muğla ilinin bir ilçesidir ve "Flora of Turkey" deki kareleme sistemine göre "C2" karesinde bulunmaktadır. Ula, Muğla'nın güneyinde 28, $25^{\circ}-28,75^{\circ}$ kuzey paralelleri ve $37^{\circ}-37,15^{\circ}$ doğu meridyenleri arasındadır. Doğusunda Köyceğiz, batısında Gökova körfezi, kuzeyinde Muğla, güneyinde Marmaris vardır. Yüzölçümü 407 km² dir. Ula merkez deniz seviyesinden 600 metre yüksekliktedir. Muğla-Ula mesafesi $15 \mathrm{~km}$, MuğlaMarmaris karayolu üzerinden gidildiğinde, anayoldan $3 \mathrm{~km}$ içeride kalır. 2016 TÜİK verilerine göre nüfusu 23877 kişidir ( Şekil 1.).

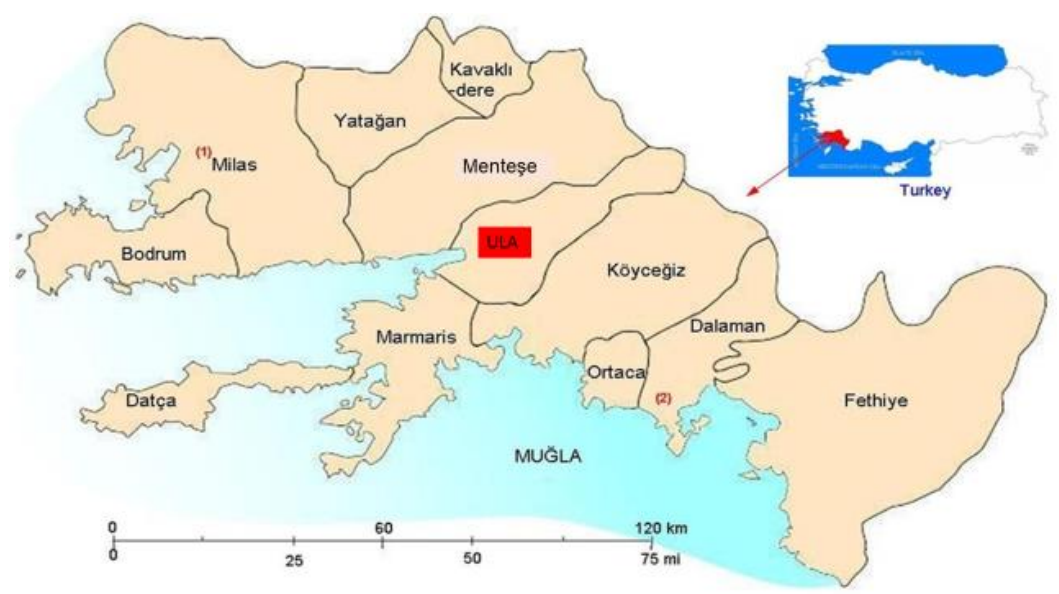

Şekil 1. Ula (Muğla) İlçe Haritası

Ula ilçesi, il merkezine en yakın ilçe olup $14 \mathrm{~km}$ mesafededir. İlçenin dört tarafı da dağlarla çevrilidir, $5 \mathrm{~km}$ kıyı uzunluğu ile denize en az kıyısı olan ilçede arazi engebeli olup \%65'i ormanlarla kaplıdır. En önemli akarsuyu ilçenin doğu sınırlarını belirleyen Namnam çayıdır. İlçede Akdeniz iklimi etkilidir. Yazlar kurak ve sıcak, kışlar ılık ve yağışlıdır.. 


\section{Materyal ve yöntem}

Ula ilçe merkezi ve bağlı 26 mahalle çalışma alanımızı oluşturmaktadır. Bu çalışmada Ula halk pazarında, meydanlarda, kahvelerde, mahallelerin muhtarlarının yönlendirdiği bitkisel tedavi uygulayan yaşlılarla evlerinde ya da kahvede toplu olarak bulabildiğimiz toplamda 128 kişi ile görüşülmüştür. Ula merkez ve halk pazarında bulunan aktarlardan da yöresel bitki kullanımları hakkında bilgi alınmıştır. Diğer kaynak kişiler gidilen mahallelerdeki yerel halktır.

Görüşülen farklı yaş ve kültür yapısındaki kişilerin; ilçe pazarındaki ve aktardaki satıcıların farklı amaçlarla kullandıkları bitkiler tespit edilmeye çalışılmıştır. Bu görüşmeler sırasında kaynak kişilere hazırladığımız anketler doğrultusunda sorular yöneltilmiştir. Anketler sonucu elde edilen bilgiler ve örneklenen bitkiler çalışmamızın araştırma materyalini oluşturmaktadır.

Anketimizin içeriğinde sorduğumuz sorular ile kullanılan bitkilerin yöresel adı, bitkinin kullanılan kısmı, kullanım amacı ve nasıl kullanıldı̆̆ına dair bilgiler, bu bilgileri kimden öğrendiği, hangi sıklıkla kullanılması gerektiği, bitki örneğinin alındığı mevkii, anket yapılan kişinin yaş, cinsiyet, eğitim durumu gibi özellikleri belirlenmeye çalışılmıştır (Ek 1).

Anketler sonucu kullanımı tespit edilen bitkilerin pazarda ve aktarda satılan kuru formlarından örnekler alınmış, ya da bitkilerin fotoğrafı çekilmiştir. Bitkilerin teşhisi 'Flora of Turkey and The East Aegean Islands [6] kaynaklarına göre yapılmıştır. 'Ege Bölgesi Bitki Örtüsü' [20] ve 'Edible Wild Plants of Turkey' [21] bitkilerle ilgili bilgiler bakımından faydalandığımız kaynaklardandır. Ayrıca Muğla Sitkı Koçman Üniversitesi Biyoloji Bölümü herbaryumundan da faydalanılmıştır. Anketlerdeki bitkilerin yöresel isimleri anket yapılan kişiye sorularak belirlenmiştir Karşılaştırma yapabilmek için ‘Türkçe Bitki Adları Sözlüğü’ [22] ve 'Tohumlu Bitkiler Sistematiği’ [23] ve 'Türkiye'de Bitkilerle Tedavi' [2] ve "Türkiye Bitkileri Listesi, Damarlı Bitkiler” [24] kitapları referans alınmıştır.

Çalışmadaki bitkilerin tanımı ve yayılış alanlarının belirlenmesi için 'Tohumlu Bitkiler Sistematiği' [23] kitab1, 'Flora of Turkey and The East Aegean Islands [6] ve Türkiye Bitkileri Veri Servisi (Tübives) internet adresinden yararlanılmıştır. Anketler sonucu belirlenen bitkilerin bilimsel adları, yöresel adları, bitki örneğinin alındığı yer, kullanılan bitkilerin özellikleri, bitkinin kullanım amacı, kullanım şekli ve kaynak kişileri belirlenmiştir.

\section{Bulgular}

Ula merkez ve 26 mahallesinde 49 kadın, 79 erkek toplam 128 kişi ile görüşülerek anket çalışmaları gerçekleştirilmiştir. Bu kişilerden 9 tanesi Ula merkezden, 119 tanesi Ula’ya bağlı mahallelerdendir. Yapılan çalışma sonucuna göre demografik özelliklere ait bilgiler Şekil 2' de verilmiştir.
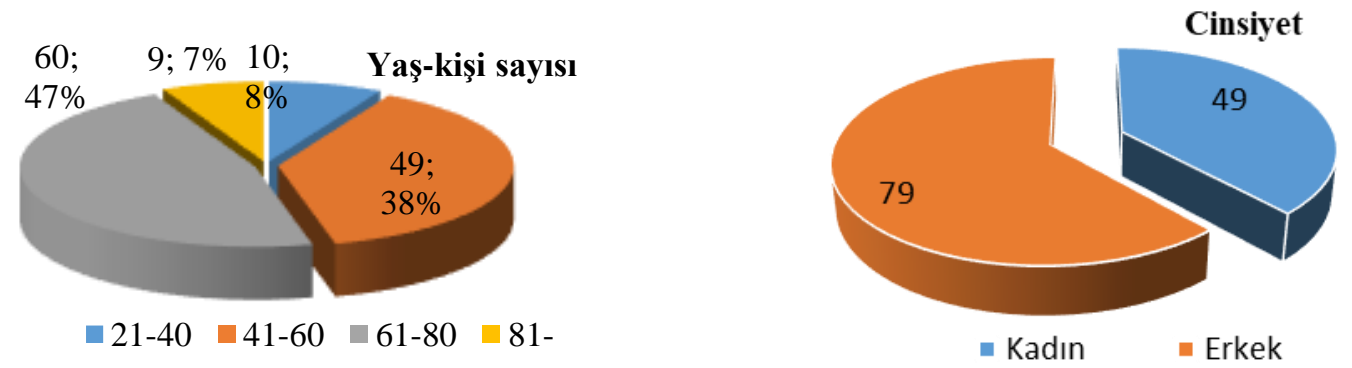

Şekil 2. Katılımcılarım yaş ve cinsiyet dağılımları

Yaptığımız alan çalışmasında erkeklerin çoğunlukta olmasının nedeni görüşmelerin daha çok kahvehanelerde, meydanlarda yapılmasıdır. Görüşülen kadınların 47'si, erkeklerin 67'si ilkokul mezunudur. İlkokul mezunu toplam 114 kişiden 109 kişinin 40 ve üstü yaşlarda olduğu görülmüştür.

Bölgede görüşülen 128 kişinin eğitim durumlarına bakıldığında 1 kişinin ilk eğitimini tamamlayamamış olduğu görülmektedir. Çalışmamızda ortaokul mezunu kimseyle görüşülmemiştir. 128 kişiden 114’ü (\%89) ilkokul, 6'sı (\%5) ön lisans, 5'i (\%4) lise, 2'si (\%1) lisans mezunu olduğu görülmüştür (Şekil 3 ).

Ula ve mahallelerinde yaptığımız etnobotanik çalışmamızın sonucunda burada yaşayan yerel halkın çeşitli bitki türlerini tedavi, gıda, baharat, yakacak, süpürge veya eşya yapımında ayrıca temizlik, bakım ve karışım halinde kullandığ1 görülmüştür. 


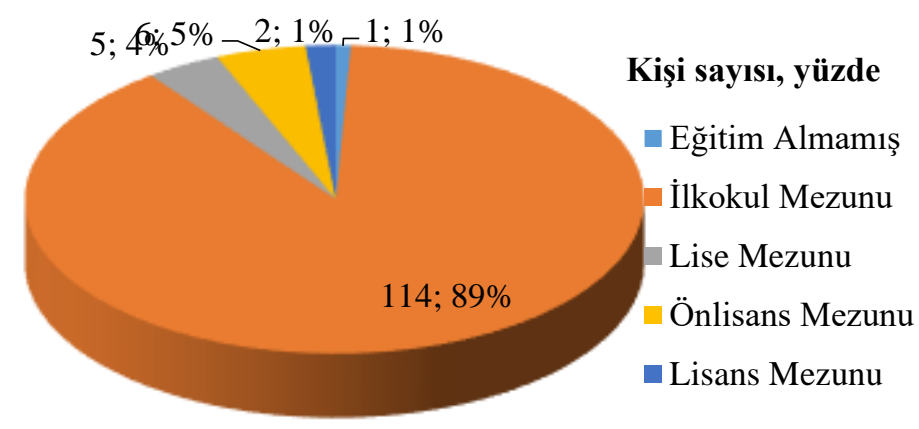

Şekil 3. Katılımcıların eğitim durumu

Araştırmalarımız sonucunda Ula merkez ve mahallelerinde tedavi amaçlı 72 adet bitki bulunmaktadır (Tablo 1). Bu bitkilerden 9 tanesi grip, nezle ve soğuk algınlığında, 8 tanesi idrar söktürücü olarak, 8 tanesi kan şekerinin düzenlenmesinde, 6 tanesi hazımsızlık tedavisinde, 5 tanesi kansızlık tedavisinde, 3 tanesi kanser tedavisinde kullanılmaktadır. Bazı bitkiler birden fazla hastalığın tedavisinde kullanılmıştır. Allium cepa L., grip, iltihap giderilmesi, burkulma tedavisinde, Arbutus unedo L., idrar söktürücü, kan şekerinin düzenlenmesinde, Lavandula stoechas L., hazımsızlık, akciğer iltihabı ve kan şekerinin düzenlenmesinde, grip ve nezle, kalp rahatsızlığ tedavisinde, Tilia rubra L., soğuk algınlığı, kansızlık, hazımsızlık tedavisinde, Salvia fruticosa Mill., nezle ve grip, karın ağrısı tedavisi, Sideritis leptoclada O. Schwarz (Endemik)., nezle ve grip, karın ağrısı tedavisi, Origanum onites L., karın ağrısı, burkulma tedavisi, mide üşütmesi, iltihap giderilmesinde kullanılmıştır.

Tablo 1. Tedavi amaçlı kullanılan bitkiler

\begin{tabular}{|c|c|c|c|c|}
\hline Familya & Latince Ad 1 & Yöresel Adı & $\begin{array}{l}\text { Kullanilan } \\
\text { kisimları } \\
\end{array}$ & $\begin{array}{l}\text { Uygulama ve kullanan kişi } \\
\text { sayısı }\end{array}$ \\
\hline \multirow{3}{*}{ Amaryllidaceae } & \multirow{2}{*}{ Allium cepa $\mathrm{L}$. } & \multirow{2}{*}{ Soğan } & Gövde-yaprak & Kanser, 3 \\
\hline & & & Kök & $\begin{array}{l}\text { Grip, burkulma, iltihap } \\
\text { giderilmesi,7 }\end{array}$ \\
\hline & Allium sativum $\mathrm{L}$. & Sarımsak & Kök & Saç kuran tedavisi, 1 \\
\hline \multirow[b]{2}{*}{ Anacardiaceae } & \multirow{2}{*}{$\begin{array}{l}\text { Pistacia terebintus L. } \\
\text { subsp. palaestina (Boiss.) } \\
\text { Engler }\end{array}$} & \multirow[b]{2}{*}{$\begin{array}{l}\text { Menevis, } \\
\text { menengiç }\end{array}$} & Genç sürgün & Yutma zorluğu, 1 \\
\hline & & & Sakız & $\begin{array}{l}\text { Hazımsızlık, yaraların } \\
\text { tamiri,3 }\end{array}$ \\
\hline \multirow{4}{*}{ Apiaceae } & Apium graveolens L. & Kereviz & $\begin{array}{l}\text { Kök-toprak üstü } \\
\text { organlar1 }\end{array}$ & Demir eksikliği tedavisi, 1 \\
\hline & $\begin{array}{l}\text { Petroselinum crispum } \\
\text { (Mill.) A. W. Hill }\end{array}$ & Maydonoz & Dal-yaprak & İdrar yolları enfeksiyonu, 3 \\
\hline & Pimpinella anisum L. & Anason & Tohum & Gaz söktürücü,1 \\
\hline & Scandix pecten-veneris L. & Kiskis & $\begin{array}{l}\text { Toprak üstü } \\
\text { organlar1 }\end{array}$ & Yutma zorluğu,1 \\
\hline Asphodelaceae & Asphodelus aestivus Brot. & Çiriş Otu & Kök & Basur tedavisi, 1 \\
\hline \multirow{4}{*}{ Asteraceae } & \multirow[b]{2}{*}{ Anthemis tictoria L. } & \multirow[b]{2}{*}{$\begin{array}{l}\text { Papatya, beyaz } \\
\text { papatya }\end{array}$} & Kapitulum & Hazımsızlık, 1 \\
\hline & & & $\begin{array}{l}\text { Toprak üstü } \\
\text { organlar1 }\end{array}$ & Grip tedavisi,2 \\
\hline & Cynara scolymus L. & Enginar & $\begin{array}{l}\text { Toprak üstü } \\
\text { organlar1 }\end{array}$ & Karaciğer rahatsızlıkları,2 \\
\hline & Helianthus annus L. & Ayçiçeği & Tohum & $\begin{array}{l}\text { Prostat, kan şekeri } \\
\text { düzenlenmesi,1 }\end{array}$ \\
\hline Boraginaceae & Borago officinalis L. & Sığır Dili & $\begin{array}{l}\text { Toprak üstü } \\
\text { kısımları }\end{array}$ & Hemoroit, prostat, 2 \\
\hline \multirow{2}{*}{ Brassicaceae } & $\begin{array}{l}\text { Brassica oleracea var. } \\
\text { capitata } \mathrm{L} \text {. }\end{array}$ & Beyaz lahana & Yaprak & $\begin{array}{l}\text { Burkulma tedavisi, karın } \\
\text { ağrısı,2 }\end{array}$ \\
\hline & Lepidium sativum L. & Tere & Tohum & Guatr tedavisi, 1 \\
\hline Capparaceae & $\begin{array}{l}\text { Capparis spinosa L. var. } \\
\text { aegyptia (Lam.) Boiss. }\end{array}$ & $\begin{array}{l}\text { Kebere, kapari, } \\
\text { gebere }\end{array}$ & Meyve & Sinüzit tedavisi, 1 \\
\hline Cupressaceae & $\begin{array}{l}\text { Cupressus sempervirens } \\
\text { L. var. pyramidalis }\end{array}$ & $\begin{array}{l}\text { Servi, mezarlık } \\
\text { servisi }\end{array}$ & Kozalak & İdrar söktürücü,1 \\
\hline Cyperaceae & Cyperus rotundus $\mathrm{L}$. & $\begin{array}{l}\text { Topalak otu- } \\
\text { Pamukluk }\end{array}$ & Gövde & Mide üşütmesi,1 \\
\hline
\end{tabular}


Tablo 1. (Devam ediyor)

\begin{tabular}{|c|c|c|c|c|}
\hline Familya & Latince Ad 1 & Yöresel Adı & $\begin{array}{l}\text { Kullanılan } \\
\text { kisimlar1 }\end{array}$ & Uygulama ve kişi sayısı \\
\hline Ericaceae & Arbutus unedo L. & Sandal & Meyve & $\begin{array}{l}\text { İdrar söktürücü, kan şekeri } \\
\text { düzenlenmesi,2 }\end{array}$ \\
\hline Euphorbiacea & $\begin{array}{l}\text { Euphorbia amygdaloides } \\
\text { L. }\end{array}$ & Sütleğen & Süt salgısı & $\begin{array}{l}\text { Böcek sokmaları, siğil } \\
\text { tedavisi,2 }\end{array}$ \\
\hline \multirow{4}{*}{ Fabaceae } & \multirow{2}{*}{ Ceratonia siliqua L. } & \multirow{2}{*}{$\begin{array}{l}\text { Keçiboynuzu, } \\
\text { harnup, harıp }\end{array}$} & Meyve-tohum & Öksürük,1 \\
\hline & & & Meyve-tohum & Bronşit,1 \\
\hline & Lens culinarisL. & Mercimek & Tohum & Demir eksikliği,1 \\
\hline & Vicia ervilia (L.) Willd. & Burçak & $\begin{array}{l}\text { Toprak üstü } \\
\text { organlar1 }\end{array}$ & Yara tedavisi,2 \\
\hline Fagaceae & Quercus coccifera L. & $\begin{array}{l}\text { Meşe, } \\
\text { Kizılpinar }\end{array}$ & Palamut & Toksik guatr tedavisi, 1 \\
\hline Hamamelidaceae & $\begin{array}{l}\text { Liquidambar orientalis } \\
\text { Mill.(End.) }\end{array}$ & Sığla, günlük & Uçucu Yağ1 & Ülser, yaraların tedavisi,5 \\
\hline Hypericaceae & $\begin{array}{l}\text { Hypericum perforatum } \mathrm{L} \text {. } \\
\text { var. perforatum }\end{array}$ & Kantaron otu & $\begin{array}{l}\text { Toprak üstü } \\
\text { organlar1 }\end{array}$ & Yanık ve yara tedavisi, 8 \\
\hline \multirow{4}{*}{ Juglandaceae } & \multirow{4}{*}{ Juglans regia L. } & \multirow{4}{*}{ Ceviz } & Tohum & Bronşit tedavisi, 1 \\
\hline & & & $\begin{array}{l}\text { Tohum kabuğu } \\
\text { püskülü }\end{array}$ & İltihap giderici,1 \\
\hline & & & Yaprak & Bademcik tedavisi, 1 \\
\hline & & & Tohum Zar1 & Bronşit tedavisi, 1 \\
\hline \multirow{12}{*}{ Lamiaceae } & \multirow[t]{2}{*}{ Lavandula stoechas L. } & \multirow[t]{2}{*}{ Karan } & $\begin{array}{l}\text { Toprak üstü } \\
\text { organlar1 }\end{array}$ & $\begin{array}{l}\text { Hazımsılık, akciğer } \\
\text { iltihabı tedavisi, kan } \\
\text { şekerinin düzenlenmesi, } 6\end{array}$ \\
\hline & & & Çiçek & $\begin{array}{l}\text { Grip ve nezle tedavisi, kalp } \\
\text { rahatsızlığ } 1 \text { tedavisi,2 }\end{array}$ \\
\hline & Mentha pulegium L. & Narpız & $\begin{array}{l}\text { Toprak üstü } \\
\text { organlar1 }\end{array}$ & Karın ağrısı tedavisi,2 \\
\hline & Mentha x piperita $\mathrm{L}$. & Nane & $\begin{array}{l}\text { Toprak üstü } \\
\text { organlar1 }\end{array}$ & $\begin{array}{l}\text { Nezle ve grip, karın ağrıs1 } \\
\text { tedavisi, } 4\end{array}$ \\
\hline & Ocimum basilicum $\mathrm{L}$. & $\begin{array}{l}\text { Fesleğen, } \\
\text { reyhan }\end{array}$ & Yaprak-çiçek & Kolesterol tedavisi, 1 \\
\hline & \multirow{2}{*}{ Origanum onites L. } & \multirow[t]{2}{*}{ Kekik } & $\begin{array}{l}\text { Toprak üstü } \\
\text { organlar1 }\end{array}$ & $\begin{array}{l}\text { Karın ağrısı, mide } \\
\text { üşütmesi, bertilme } \\
\text { tedavisi, } 15\end{array}$ \\
\hline & & & Uçucu Yağı & Karın ağrısı,3 \\
\hline & Rosmarinus officinalis L. & Biberiye & Dal-yaprak & $\begin{array}{l}\text { Tansiyon, damar açıcı, ağrı } \\
\text { kesici,2 }\end{array}$ \\
\hline & Salvia fruticosa Mill. & $\begin{array}{l}\text { Adaçayı, çalba, } \\
\text { geyik elması }\end{array}$ & $\begin{array}{l}\text { Toprak üstü } \\
\text { organları }\end{array}$ & $\begin{array}{l}\text { Nezle-grip, karın ağrısı } \\
\text { tedavisi,6 }\end{array}$ \\
\hline & $\begin{array}{l}\text { Sideritis leptoclada O. } \\
\text { Schwarz et P.H. Davis } \\
\text { (Endemik) }\end{array}$ & $\begin{array}{l}\text { Kızlan çayı, dağ } \\
\text { çayı }\end{array}$ & $\begin{array}{l}\text { Toprak üstü } \\
\text { organları }\end{array}$ & $\begin{array}{l}\text { Nezle-grip, karın ağrısı } \\
\text { tedavisi,3 }\end{array}$ \\
\hline & Teucrium chamaedrys L. & Bodurcamahmut & $\begin{array}{l}\text { Toprak üstü } \\
\text { organlar1 }\end{array}$ & İdrar yolları enfeksiyonu, 1 \\
\hline & Teucrium polium L. & $\begin{array}{l}\text { Yavsancık- } \\
\text { Epiryavşan Otu }\end{array}$ & $\begin{array}{l}\text { Toprak üstü } \\
\text { organları }\end{array}$ & $\begin{array}{l}\text { Kan şekerinin } \\
\text { düzenlenmesi, } 1\end{array}$ \\
\hline \multirow[b]{3}{*}{ Lauraceae } & \multirow[t]{2}{*}{ Cinnamomum verum $\mathrm{L}$. } & \multirow[t]{2}{*}{ Tarçın } & Gövde örtüsü & $\begin{array}{l}\text { Kan şekerinin } \\
\text { düzenlenmesi, } 1\end{array}$ \\
\hline & & & Meyve & Romatizma tedavisi,2 \\
\hline & Laurus nobilis L. & $\begin{array}{l}\text { Defne, tenel, } \\
\text { teğnel }\end{array}$ & Uçucu Yağ1 & $\begin{array}{l}\text { Kas yorgunluğu, tansiyon } \\
\text { düşürücü, } 2\end{array}$ \\
\hline Liliaceae & Urginea maritima Baker & Ada Soğanı & Kök-yaprak & Kas ağrısı tedavisi, 1 \\
\hline Linaceae & Linum usitatissimum L. & Keten & Tohum & $\begin{array}{l}\text { Hazımsılılı, gaz sanc1sı } \\
\text { tedavisi,1 }\end{array}$ \\
\hline Lythraceae & Punica granatum L. & Nar & Meyve & Kansızlık tedavisi,1 \\
\hline
\end{tabular}


Tablo 1. (Devam ediyor)

\begin{tabular}{|c|c|c|c|c|}
\hline Familya & Latince Ad 1 & Yöresel Adı & $\begin{array}{l}\text { Kullanılan } \\
\text { kisımlar1 }\end{array}$ & Uygulama ve kişi sayısı \\
\hline \multirow{3}{*}{ Malvaceae } & \multirow[t]{2}{*}{ Hibiscus esculenthus L. } & \multirow{2}{*}{ Bamya } & Çiçek & Astım, bronşit tedavisi, 1 \\
\hline & & & Meyve & İltihap, çıban tedavisi,1 \\
\hline & Malva sylvestris $\mathrm{L}$. & Ebegömeci otu & $\begin{array}{l}\text { Toprak üstü } \\
\text { organları }\end{array}$ & $\begin{array}{l}\text { Burkulma, incinme } \\
\text { tedavisi, } 1\end{array}$ \\
\hline \multirow{3}{*}{ Moraceae } & $\begin{array}{l}\text { Ficus carica L. subsp. } \\
\text { carica } \text { var. caprificus } \\
\text { Tsch. et Rav }\end{array}$ & $\begin{array}{l}\text { İncir Boğas1, } \\
\text { erkek incir }\end{array}$ & Meyve & Bronşit, kabızlık tedavisi,2 \\
\hline & Morus alba $\mathrm{L}$. & Dut & Yaprak & $\begin{array}{l}\text { Kan şekerinin } \\
\text { düzenlenmesi, } 1\end{array}$ \\
\hline & Morus nigra $\mathrm{L}$. & Karadut & Meyve & $\begin{array}{l}\text { Sindirim sistemi yaralarının } \\
\text { tamiri, } 1\end{array}$ \\
\hline Oleaceae & $\begin{array}{l}\text { Olea europea L. var. } \\
\text { sylvestris (Mill.) Lehr }\end{array}$ & Zeytin & Meyve yağ 1 & $\begin{array}{l}\text { Burkulma, iltihap, bronşit } \\
\text { tedavisi,4 }\end{array}$ \\
\hline Pedaliaceae & Sesamum indicum L. & Susam & Tohum & $\begin{array}{l}\text { Yeni doğanda gaz sancısı } \\
\text { tedavisi,2 }\end{array}$ \\
\hline \multirow[b]{2}{*}{ Pinaceae } & Pinus brutia Ten. & Çam, kızılçam & Genç filiz & Kansızlık tedavisinde, 1 \\
\hline & $\begin{array}{l}\text { Pinus nigra Arn } \\
\text { subsp.,pallasina (lamb) } \\
\text { Holmboe }\end{array}$ & Karaçam & Akma & Egzama tedavisinde, 1 \\
\hline Platanaceae & Platanus orientalis L. & Kavak & Yaprak & Kemik erimesi tedavisi, 1 \\
\hline \multirow{5}{*}{ Poaceae } & $\begin{array}{l}\text { Cynodon dactylon } \\
\text { (L.)Pers. }\end{array}$ & Ayrik otu & Kök & $\begin{array}{l}\text { İdrar söktürücü, iltihap } \\
\text { giderici, basur tedavisinde, } 2\end{array}$ \\
\hline & Hordeum vulgare L. & Arpa & Tohum & $\begin{array}{l}\text { Böbrek taş1 tedavisi, yara- } \\
\text { burkulma tedavisinde, } 3\end{array}$ \\
\hline & & & Tohum & $\begin{array}{l}\text { İneklerde plasenta } \\
\text { düşürülmesi,2 }\end{array}$ \\
\hline & Triticum aestivum $\mathrm{L}$. & Buğday & Genç sürgün & $\begin{array}{l}\text { Yumurtalık kanseri } \\
\text { tedavisinde, } 1\end{array}$ \\
\hline & Zea mays L. & Misir & Püskül & $\begin{array}{l}\text { İdrar söktürücü, böbrek } \\
\text { taşının düşürülmesi,3 }\end{array}$ \\
\hline Punicaceae & Punica granatum L. & Nar & Yaprak & Hazımsızlık tedavisinde, 1 \\
\hline Rhamnaceae & $\begin{array}{l}\text { Paliurus spina-christi } \\
\text { Mill. }\end{array}$ & $\begin{array}{l}\text { Karaçalı, } \\
\text { karaçalı diken }\end{array}$ & Tohum & Böbrek taşı tedavisi,2 \\
\hline \multirow{8}{*}{ Rosaceae } & \multirow[t]{2}{*}{ Armeniaca vulgaris Lam. } & \multirow{2}{*}{ Kayı1 1} & Meyve sap1 & Kabızlık tedavisinde, 1 \\
\hline & & & Meyve & Kabızlık tedavisinde, 1 \\
\hline & Cerasus vulgaris Mill. & Vişne & Meyve sap1 & İdrar söktürücü,1 \\
\hline & $\begin{array}{l}\text { Cerasus avium (L) } \\
\text { Moench }\end{array}$ & Kiraz & Meyve sap1 & İdrar söktürücü,1 \\
\hline & Cydonia oblonga Mill. & Ayva & Yaprak & İshal tedavisi,2 \\
\hline & Malus sylvestris Mill. & Elma & Meyve & Burkulma tedavisi, 1 \\
\hline & Rosa canina $\mathrm{L}$. & Kuşburnu & Meyve & $\begin{array}{l}\text { Kansızlık, kan şekerinin } \\
\text { düzenlenmesi,2 }\end{array}$ \\
\hline & Rubus sanctus Schreber. & Böğürtlen & Kök & Hazımsızlık tedavisi,1 \\
\hline \multirow{2}{*}{ Rutaceae } & Citrus aurantiifoli L. & Bergamut & Meyve & Öksürük tedavisi, 1 \\
\hline & Citrus limon $\mathrm{L}$. & Limon & Meyve & $\begin{array}{l}\text { Soğuk algınlığı, nezle-grip } \\
\text { tedavisi,3 }\end{array}$ \\
\hline Salicaceae & Populus tremula & Selvi & Yaprak & Baş ağrısı tedavisi,1 \\
\hline Solanaceae & Solanum nigrum L. & Köpek sirkeni & Meyve & Çıban tedavisi, 1 \\
\hline Tiliaceae & Tilia rubra $\mathrm{L}$. & Ihlamur & Dal-yaprak & $\begin{array}{l}\text { Soğuk algınlığı, kansızlık, } \\
\text { hazımsılık tedavisi,5 }\end{array}$ \\
\hline Urticaceae & Urtica dioica $\mathrm{L}$. & Isırgan otu & $\begin{array}{l}\text { Toprak üstü } \\
\text { organları }\end{array}$ & Kanser tedavisi, 1 \\
\hline Verbenaceae & Vitex agnus-castus L. & Hayıt & Yaprak & Karın ve baş ağrısı tedavisi,2 \\
\hline Vitaceae & Vitis vinifera $\mathrm{L}$. & Üzüm & Meyve-tohum & Kansızlık tedavisi, 1 \\
\hline
\end{tabular}


Yapılan çalışmalar sonucunda 69 bitki türünün baharat, gıda ve içecek olarak kullanıldığı görülmüşs (Tablo 2), bunlardan Citrus nobilis Lour., ve Citrus sinensis (L.) Osbeck., Capsicum annum L., en fazla oranda tüketilen bitkilerdir.

Tablo 2. Gida ve baharat olarak kullanılan bitkiler

\begin{tabular}{|c|c|c|c|c|}
\hline Familya & Latince Ad 1 & Yöresel Adı & $\begin{array}{l}\text { Kullanılan } \\
\text { kisımları }\end{array}$ & $\begin{array}{l}\text { Yemek -baharat } \\
\text { ve kişi sayısı }\end{array}$ \\
\hline \multirow[t]{3}{*}{ Amaryllidaceae } & Allium cepa $\mathrm{L}$. & Soğan & Kök-Yaprak & Yemek, 1 \\
\hline & Allium porrum L. & Pirasa & Kök-Yaprak & Yemek,2 \\
\hline & Allium sativum L. & Sarımsak & Kök-Yaprak & Yemek, 1 \\
\hline Anacardiaceae & Rhus coriaria $\mathrm{L}$. & Sumak & Meyve & Baharat,2 \\
\hline \multirow{5}{*}{ Apiaceae } & Anethum graveolens $L$. & Dereotu & $\begin{array}{l}\text { Topraküstü } \\
\text { organları }\end{array}$ & Yemek, 1 \\
\hline & Apium graveolens $L$. & Kereviz & $\begin{array}{l}\text { Topraküstü } \\
\text { organlar1 }\end{array}$ & Yemek,2 \\
\hline & Oenanthe pimpinelloides L. & $\begin{array}{l}\text { Gazayak, } \\
\text { gazyak }\end{array}$ & $\begin{array}{l}\text { Topraküstü } \\
\text { organlar1 }\end{array}$ & Yemek, 1 \\
\hline & $\begin{array}{l}\text { Petroselinum crispum (Mill.) A. } \\
\text { W. Hill }\end{array}$ & Maydonoz & Yaprak & Yemek,3 \\
\hline & Scandix pecten-veneris L. & Kiskis & $\begin{array}{l}\text { Topraküstü } \\
\text { organları }\end{array}$ & Yemek,3 \\
\hline Aracaceae & Cocos nucifera $\mathrm{L}$. & $\begin{array}{l}\text { Hindistan } \\
\text { Cevizi }\end{array}$ & Meyve & Yemek, 1 \\
\hline Asparagaceae & Asparagus acutifolius $L$. & $\begin{array}{l}\text { Tilkimen, } \\
\text { Tilkişen }\end{array}$ & Genç Sürgün & Yemek, 1 \\
\hline \multirow{2}{*}{$\begin{array}{l}\text { Asteraceae } \\
\text { (Compositae) }\end{array}$} & Cynara scolymus L. & Enginar & $\begin{array}{l}\text { Topraküstü } \\
\text { organları }\end{array}$ & Yemek,2 \\
\hline & Tragopogon porrifolius $L$. & Dede sakalı & $\begin{array}{l}\text { Toprak üstü } \\
\text { organlar1 }\end{array}$ & Yemek, 1 \\
\hline $\begin{array}{l}\text { Brassicaceae } \\
\text { (Cruciferae) }\end{array}$ & $\begin{array}{l}\text { Brassica oleracea var. capitata } \\
\text { L. }\end{array}$ & Beyaz lahana & Yaprak & Yemek,1 \\
\hline \multirow{2}{*}{ Chenopodiaceae } & Salicornia europaea $L$. & $\begin{array}{l}\text { Deniz } \\
\text { Börülcesi }\end{array}$ & $\begin{array}{l}\text { Toprak üstü } \\
\text { organları }\end{array}$ & Yemek,3 \\
\hline & Beta maritima L. var. maritima & Pancar, mancar & Kök & Yemek,1 \\
\hline Corylaceae & Corylus maxima Mill. & Findık & Tohum & Yemek,1 \\
\hline \multirow{5}{*}{ Cucurbitaceae } & $\begin{array}{l}\text { Citrillus lanatus (Thunb.) } \\
\text { Matsum. et. Naksi. }\end{array}$ & Karpuz & Meyve & Yemek,2 \\
\hline & Cucumis sativus L. & Salatalik & Meyve & Yemek, 1 \\
\hline & Cucumis melo L. & Kavun & Meyve & Yemek,2 \\
\hline & Cucurbita pepo L. & $\begin{array}{l}\text { Ak kabak, } \\
\text { kabak }\end{array}$ & Meyve & Yemek,2 \\
\hline & Arachis hypogaea L. & Fist1k & Tohum & Yemek,1 \\
\hline \multirow{5}{*}{$\begin{array}{l}\text { Fabaceae } \\
\text { (Leguminosae ) }\end{array}$} & Lens culinaris Medik & Mercimek & Tohum & Yemek,1 \\
\hline & Medicago sativa $L$. & Yonca & $\begin{array}{l}\text { Topraküstü } \\
\text { organları }\end{array}$ & Yemek,2 \\
\hline & Phaseolus vulgaris $L$. & Fasulye & Tohum-Meyve & Yemek,2 \\
\hline & Vicia faba $\mathrm{L}$ & Börek bakla & Meyve-Yaprak & Yemek, 1 \\
\hline & Vigna anguiculata (L.)Walp. & Börülce & Meyve-Tohum & Yemek,2 \\
\hline Juglandaceae & Juglans regia L. & Ceviz & Meyve & Yemek, 1 \\
\hline $\begin{array}{l}\text { Lamiaceae } \\
\text { (Labiatae) }\end{array}$ & Origanum onites L. & Kekik & $\begin{array}{l}\text { Toprak üstü } \\
\text { organlar1 }\end{array}$ & Baharat, 1 \\
\hline Lythraceae & Punica granatum $\mathrm{L}$. & Nar & Meyve & Yemek,1 \\
\hline \multirow{2}{*}{ Malvaceae } & Hibiscus esculenthus L. & Bamya & Meyve & Yemek, 1 \\
\hline & Malva sylvestris $\mathrm{L}$. & $\begin{array}{l}\text { Ebegümeci, } \\
\text { ebegümeç }\end{array}$ & $\begin{array}{l}\text { Toprak üstü } \\
\text { organlar1 }\end{array}$ & Yemek,2 \\
\hline \multirow[t]{3}{*}{ Moraceae } & $\begin{array}{l}\text { Ficus carica L. subsp. carica } \\
\text { var. caprificus Tsch. et Rav. }\end{array}$ & $\begin{array}{l}\text { İncir Boğası, } \\
\text { erkek incir }\end{array}$ & Meyve & Yemek, 1 \\
\hline & Morus alba L. & Dut & Meyve & Yemek,1 \\
\hline & Morus nigra L. & Karadut & Meyve & Yemek,1 \\
\hline
\end{tabular}


Tablo 2. (Devam ediyor)

\begin{tabular}{|c|c|c|c|c|}
\hline Familya & Latince Ad 1 & Yöresel Adı & $\begin{array}{l}\text { Kullanilan } \\
\text { kisimlar1 }\end{array}$ & $\begin{array}{l}\text { Yemek -baharat } \\
\text { ve kişi sayısı }\end{array}$ \\
\hline Musaceae & Musa sapientum $\mathrm{L}$. & $\mathrm{Muz}$ & Meyve & Yemek, 1 \\
\hline Oleaceae & $\begin{array}{l}\text { Olea europea L. var. sylvestris } \\
\text { (Mill.) Lehr }\end{array}$ & Zeytin & Meyve & Yemek,2 \\
\hline Pedaliaceae & Sesamum indicum L. & Susam & Tohum & Yemek,3 \\
\hline \multirow{7}{*}{ Poaceae } & Avena sativa $L$. & Yulaf & Tohum & Yemek, 1 \\
\hline & \multirow[b]{2}{*}{ Hordeum vulgare $\mathrm{L}$. } & \multirow[b]{2}{*}{ Arpa } & Tohum & Yemek,4 \\
\hline & & & $\begin{array}{l}\text { Toprak üstü } \\
\text { organlar1 }\end{array}$ & Yemek, 1 \\
\hline & \multirow[b]{2}{*}{ Triticum aestivum $\mathrm{L}$. } & \multirow[b]{2}{*}{ Buğday } & Tohum & Yemek, 1 \\
\hline & & & $\begin{array}{l}\text { Toprak üstü } \\
\text { organlar1 }\end{array}$ & Yemek,5 \\
\hline & \multirow{2}{*}{ Zea mays L. } & \multirow{2}{*}{ Misir } & $\begin{array}{l}\text { Toprak üstü } \\
\text { organlar1 }\end{array}$ & Yemek,2 \\
\hline & & & Tohum & Yemek,3 \\
\hline Polygonaceae & Rumex acetosella $\mathrm{L}$. & Kuzu Kulağ1 & $\begin{array}{l}\text { Toprak üstü } \\
\text { organlar1 }\end{array}$ & Yemek, 1 \\
\hline Punicaceae & Punica granatum L. & Nar & Meyve & Yemek, 1 \\
\hline \multirow{11}{*}{ Rosaceae } & Armeniaca vulgaris Lam. & Kayıs1 & Meyve & Yemek, 1 \\
\hline & Amygdalus communis L. & Badem & Tohum & Yemek, 1 \\
\hline & Cerasus vulgaris Mill. & Vişne & Meyve & Yemek,1 \\
\hline & Cerasus avium (L) Moech & Kiraz & Meyve & Yemek, 1 \\
\hline & Cydonia oblonga Mill. & Ayva & Meyve & Yemek,2 \\
\hline & Fragaria vesca $L$ & Çilek & Meyve & Yemek, 1 \\
\hline & Malus sylvestris Mill. & Elma & Meyve & Yemek, 1 \\
\hline & Prunus percica $\mathrm{L}$. & Şeftali & Meyve & Yemek,1 \\
\hline & $\begin{array}{l}\text { Pyrus amygdaliformis Vill. var. } \\
\text { amygdaliformis }\end{array}$ & $\begin{array}{l}\text { Çöğür, ahlat, } \\
\text { aklat }\end{array}$ & Meyve & Yemek, 1 \\
\hline & Pyrus communis $L$. & Armut & Meyve & Yemek, 1 \\
\hline & Rosa canina $\mathrm{L}$. & Kuşburnu & Meyve & Yemek,2 \\
\hline \multirow[t]{4}{*}{ Rutaceae } & Citrus limon $\mathrm{L}$. & Limon & Meyve & Yemek, 1 \\
\hline & Citrus nobilis Lour. & Mandalina & Meyve & Yemek,4 \\
\hline & Citrus paradisi $\mathrm{McFad}$ & Greyfurt & Meyve & Yemek, 1 \\
\hline & Citrus sinensis (L.) Osbeck. & Portakal & Meyve & Yemek,5 \\
\hline \multirow{4}{*}{ Solanaceae } & Capsicum annum $\mathrm{L}$. & Biber & Meyve & Baharat, Yemek,3 \\
\hline & Capsicum lycopersicum L. & Domates & Meyve & Yemek,2 \\
\hline & Solanum melongena L. & Patlican & Meyve & Yemek,2 \\
\hline & Solanum tuberosum L. & Patates & Kök & Yemek,2 \\
\hline Theaceae & Camellia sinensis L. & Çay & Yaprak & İçecek,1 \\
\hline Tiliaceae & Tilia rubra $\mathrm{L}$. & Ihlamur & Yaprak & İçecek, 1 \\
\hline Urticaceae & Urtica dioica $\mathrm{L}$. & Isırgan otu & $\begin{array}{l}\text { Toprak üstü } \\
\text { organlar1 }\end{array}$ & Yemek, 1 \\
\hline Vitaceae & Vitis vinifera $\mathrm{L}$. & Üzüm & Meyve & Yemek,2 \\
\hline Zingiberaceae & Zingiber officinale Roscoe & Zencefil & Kök & Baharat,1 \\
\hline
\end{tabular}

Yapılan çalışmalar sonucunda 26 bitki türünün çeşitli eşya yapımında ve yakacak olarak kullanıldığı görülmüştür ( Tablo 3). Pinus nigra Arn subsp..pallasina (Lamb) Holmboe ve Platanus orientalis L. hem yakacak hem de çeşitli eşya yapımında en sık kullanılan bitki türleri olmuştur. Bunun sebebi bu bitkilerin bölgede geniş yayılışa sahip olmasıdır. 
Tablo 3. Çeşitli eşya ve yakacak olarak kullanılan bitkiler

\begin{tabular}{|c|c|c|c|c|}
\hline Familya & Latince Ad 1 & Yöresel Adı & $\begin{array}{l}\text { Kullanılan } \\
\text { kisımlar1 }\end{array}$ & $\begin{array}{l}\text { Kullanım tipi, kişi } \\
\text { sayısı }\end{array}$ \\
\hline & Pistacia lenticus L & Sakız Ağacı & Gövde & Kaşık, 1 \\
\hline Anacardiaceae & $\begin{array}{l}\text { Pistacia terebintus L. subsp. } \\
\text { palaestina (Boiss.) Engler }\end{array}$ & $\begin{array}{l}\text { Menevis, } \\
\text { menengiç }\end{array}$ & Gövde & Toprak sürgüsü,1 \\
\hline Apocynaceae & Nerium oleander L. & $\begin{array}{l}\text { Zakkum, ay } \\
\text { ağacı }\end{array}$ & Gövde-dal & Çapa-kürek sapı,1 \\
\hline Betulaceae & Carpinus betulus L. & Gürgen & Gövde-dal & Kaş1k,1 \\
\hline \multirow{3}{*}{ Cupressaceae } & \multirow[t]{2}{*}{ Juniperus drupacea Lab. } & \multirow[t]{2}{*}{ Andız } & Gövde-kozalak & İzolasyon sıv1s1, 1 \\
\hline & & & Gövde & İp kirman1, 1 \\
\hline & Juniperus foetidissima Willd. & Ardıç & Gövde-dal & Ekmek yabası, 1 \\
\hline Ericaceae & Arbutus unedo L. & Sandal & Gövde-dal & $\begin{array}{l}\text { Kaşık, ekmek hapazı, } \\
\text { et dibeği, } 3\end{array}$ \\
\hline Fagaceae & Quercus coccifera $\mathrm{L}$. & Kizıl pinar & Gövde-dal & Toprak sürgüsü,3 \\
\hline Hamamelidaceae & $\begin{array}{l}\text { Liquidambar orientalis } \\
\text { Mill.(End.) }\end{array}$ & Sığla, günlük & Dal, gövde & Yakacak, 1 \\
\hline Juglandaceae & Juglans regia $L$. & Ceviz & $\begin{array}{l}\text { Toprak üstü } \\
\text { organları }\end{array}$ & Yakacak, 1 \\
\hline Meliaceae & Melia azederach L. & Tesbih Ağacı & Gövde & Sirık yapımı, 1 \\
\hline \multirow[t]{2}{*}{ Moraceae } & $\begin{array}{l}\text { Ficus carica L. subsp. carica } \\
\text { var. caprificus Tsch. et Rav. }\end{array}$ & $\begin{array}{l}\text { İncir Boğası, } \\
\text { erkek incir }\end{array}$ & Gövde-dal & Yakacak, 1 \\
\hline & Morus alba L. & Dut & Gövde-dal & Et dibeği,1 \\
\hline Myrtaceae & $\begin{array}{l}\text { Eucalyptus camaldulensis } \\
\text { Dehnh. }\end{array}$ & Sulfata & Gövde-dal & Tavan kerestesi,2 \\
\hline \multirow{3}{*}{ Pinaceae } & Pinus brutia Ten & Çam, kızılçam & Gövde-dal & $\begin{array}{l}\text { Saban, sürgü, } \\
\text { boyunluk yapımı,2 }\end{array}$ \\
\hline & $\begin{array}{l}\text { Pinus nigra Arn } \\
\text { subsp.,pallasina } \\
\text { (lamb)Holmboe }\end{array}$ & Karaçam & Gövde-dal & $\begin{array}{l}\text { Kovan, dibek, yayık } \\
\text { yapımı, } 6\end{array}$ \\
\hline & Pinus pinea $\mathrm{L}$. & F1st1k çamı & Gövde-dal & Sürgü, dibek yapımı,1 \\
\hline \multirow[t]{2}{*}{ Platanaceae } & Platanus orientalis L. & Kavak & Gövde-dal & $\begin{array}{l}\text { Sürgü, kovan, dibek } \\
\text { yapımı, } 7\end{array}$ \\
\hline & Arundo donax & Saz Karg1 & $\begin{array}{l}\text { Gövde-dal- } \\
\text { yaprak }\end{array}$ & $\begin{array}{l}\text { Hasır, kilim, sepet } \\
\text { yapımı, } 1\end{array}$ \\
\hline Poaceae & Sorghum vulgare $L$. & Süpürge Otu & $\begin{array}{l}\text { Toprak üstü } \\
\text { organlar1 }\end{array}$ & Süpürge, 3 \\
\hline \multirow[b]{2}{*}{ Rosaceae } & Pyrus communis $L$. & Armut & Gövde & Dibek, kaşık, hapaz,3 \\
\hline & $\begin{array}{l}\text { Pyrus amygdaliformis Vill. var. } \\
\text { amygdaliformis }\end{array}$ & Çöğür & Gövde & $\begin{array}{l}\text { Et kesme tahtas1, dibek } \\
\text { yapımı1 }\end{array}$ \\
\hline \multirow[t]{2}{*}{ Salicaceae } & Populus tremula & Selvi & Gövde-dal & $\begin{array}{l}\text { Tavan kerestesi, dibek, } \\
\text { Hapaz, } 1\end{array}$ \\
\hline & Salix fragilia $\mathrm{L}$. & Karg1-Söğüt & Gövde-dal & Sepet, 1 \\
\hline Thymelaceae & $\begin{array}{l}\text { Daphne gnidioides Jaub. et } \\
\text { Spach }\end{array}$ & $\begin{array}{l}\text { Eğircik çalısı, } \\
\text { iğircik, emicik }\end{array}$ & Gövde-yaprak & Süpürge, 1 \\
\hline Typhaceae & $\begin{array}{l}\text { Typha domingensis (Pers) } \\
\text { Steudel }\end{array}$ & Hasir Otu & $\begin{array}{l}\text { Toprak üstü } \\
\text { organlar1 }\end{array}$ & Hasir, sepet, 1 \\
\hline
\end{tabular}

Yapılan çalışmalar sonucunda 11 farklı karışımda 16 adet bitki türü tespit edilmiştir (Tablo 4). 12 adet bitkinin tedavi amaçlı kullanıldığı gibi gıda olarak da kullanıldığı görülmüştür. Allium cepa L., Origanum onites L., Mentha x piperita L., bu tür karışımlarda en çok kullanılan bitki türleri olarak görülmüştür. 
Tablo 4. Karışım olarak kullanılan bitkiler

\begin{tabular}{|c|c|c|c|c|c|c|}
\hline Familya & Bilimsel Adı & $\begin{array}{l}\text { Yerel } \\
\text { İsmi }\end{array}$ & Kullanılan Kısmı & $\begin{array}{l}\text { Kullanım } \\
\text { Amacı }\end{array}$ & $\begin{array}{l}\text { Kullanım } \\
\text { Şekli }\end{array}$ & $\begin{array}{l}\text { Kişi } \\
\text { sayıs1 }\end{array}$ \\
\hline Amaryllidaceae & Allium cepa $\mathrm{L}$. & Soğan & $\begin{array}{l}\text { Toprak üstü } \\
\text { organlar1 }\end{array}$ & \multirow{3}{*}{ Tibbi } & \multirow{3}{*}{ Lapa } & \multirow{3}{*}{1} \\
\hline Lamiaceae & Origanum onites L. & Kekik & T.üstü organları & & & \\
\hline Lamiaceae & Mentha $x$ piperita $\mathrm{L}$. & Nane & T.üstü organları & & & \\
\hline Lamiaceae & Origanum onites L. & Soğan & Kök & \multirow[b]{3}{*}{ Tibbi } & \multirow[b]{3}{*}{ Lapa } & \multirow[b]{3}{*}{3} \\
\hline Lamiaceae & Mentha $x$ piperita $\mathrm{L}$. & Kekik & T.üstü organları & & & \\
\hline Pinaceae & $\begin{array}{l}\text { Pinus nigra Arn } \\
\text { subsp., pallasina } \\
\text { (lamb) Holmboe }\end{array}$ & Karaçam & Kozalak & & & \\
\hline Anacardiaceae & Pistacia terebinthus L. & $\begin{array}{l}\text { Meneviş, } \\
\text { Menengiç }\end{array}$ & Genç sürgünler & \multirow{2}{*}{ Tibbi } & \multirow{2}{*}{ Doğrudan } & \multirow{2}{*}{1} \\
\hline Apiaceae & $\begin{array}{l}\text { Scandix pecten-veneris } \\
\text { L. }\end{array}$ & $\begin{array}{l}\text { Kişkiş, } \\
\text { Kingiş }\end{array}$ & T.üstü organları & & & \\
\hline Apiaceae & $\begin{array}{l}\text { Scandix pecten-veneris } \\
\text { L. }\end{array}$ & $\begin{array}{l}\text { Kişkiş, } \\
\text { Kingiş }\end{array}$ & T.üstü organları & \multirow{3}{*}{ Gida } & \multirow{3}{*}{ Pişirilerek } & \multirow{3}{*}{1} \\
\hline Apiaceae & Anethum graveolens L. & Dereotu & T.üstü organları & & & \\
\hline Asteraceae & $\begin{array}{l}\text { Tragopogon } \\
\text { porrifolius } \mathrm{L} .\end{array}$ & $\begin{array}{l}\text { Dede } \\
\text { sakalı }\end{array}$ & T.üstü organları & & & \\
\hline Asphodelaceae & Asphodelus aestivus L. & $\begin{array}{l}\text { Kiriş otu, } \\
\text { Çiriş otu }\end{array}$ & Kök & \multirow[t]{2}{*}{ Tibbi } & \multirow[t]{2}{*}{ Lapa } & \multirow[t]{2}{*}{1} \\
\hline Amaryllidaceae & Allium sativum $\mathrm{L}$. & Sarımsak & Kök & & & \\
\hline Cyperaceae & Cyperus rotundus $\mathrm{L}$ & $\begin{array}{l}\text { Topalak } \\
\text { otu }\end{array}$ & T.üstü organları & \multirow{3}{*}{ Tibbi } & \multirow{3}{*}{ Lapa } & \multirow{3}{*}{1} \\
\hline Lamiaceae & Ocimum basilicum $\mathrm{L}$. & Fesleğen & Yaprak & & & \\
\hline Lamiaceae & Origanum onites L. & Kekik & T.üstü organları & & & \\
\hline Amaryllidaceae & Allium сера $\mathrm{L}$. & Soğan & Kök & \multirow{3}{*}{ Tibbi } & \multirow{3}{*}{ Dekoksiyon } & \multirow{3}{*}{1} \\
\hline Lamiaceae & Origanum onites L. & Nane & T.üstü organları & & & \\
\hline Rutaceae & Citrus limon L. & Limon & Meyve & & & \\
\hline Lamiaceae & Origanum onites L. & Nane & T.üstü organları & \multirow{2}{*}{ Tibbi } & \multirow{2}{*}{ Lapa } & \multirow{2}{*}{4} \\
\hline Oleaceae & Olea europaea L. & Zeytin & Yağ & & & \\
\hline Moraceae & $\begin{array}{l}\text { Ficus carica L. subsp. } \\
\text { carica var. caprificus } \\
\text { Tsch. et Rav. }\end{array}$ & İncir & Meyve & \multirow[t]{2}{*}{ Tibbi } & \multirow[t]{2}{*}{ Doğrudan } & \multirow[t]{2}{*}{1} \\
\hline Oleaceae & Olea europaea L. & Zeytin & Yağ & & & \\
\hline Oleaceae & Olea europaea L. & Zeytin & Yağ & \multirow{2}{*}{ Tibbi } & \multirow{2}{*}{ Kaynatılarak } & \multirow{2}{*}{1} \\
\hline Rutaceae & Citrus limon L. & Limon & Meyve & & & \\
\hline Verbenaceae & Vitex agnus-castus L. & Hayıt & Yaprak & \multirow{2}{*}{ Tibbi } & \multirow{2}{*}{ Lapa } & 1 \\
\hline Oleaceae & Olea europaea L. & Zeytin & Yăg & & & 1 \\
\hline
\end{tabular}

\section{Sonuçlar ve tartışma}

Bölgede halkın kullandığı 123 bitki türünden 12'si \% 15 temsil oranıyla Rosaceae familyasına aittir (Şekil 4). Rosaceae familyasına ait türlerin daha fazla kullanılmasının nedeni, bölgede tarımının yüksek miktarlarda yapılması ve dolayısıyla her türlü tüketiminin bölgede yaygın olmasından kaynaklanmaktadır. Çalışma alanımıza yakın Bodrum [14], Datça [16], Fethiye [17], Marmaris [18], Ortaca [25] gibi alanlarda yapılan diğer etnobotanik çalışmalarında da benzer sonuçlar görülmüştür. 


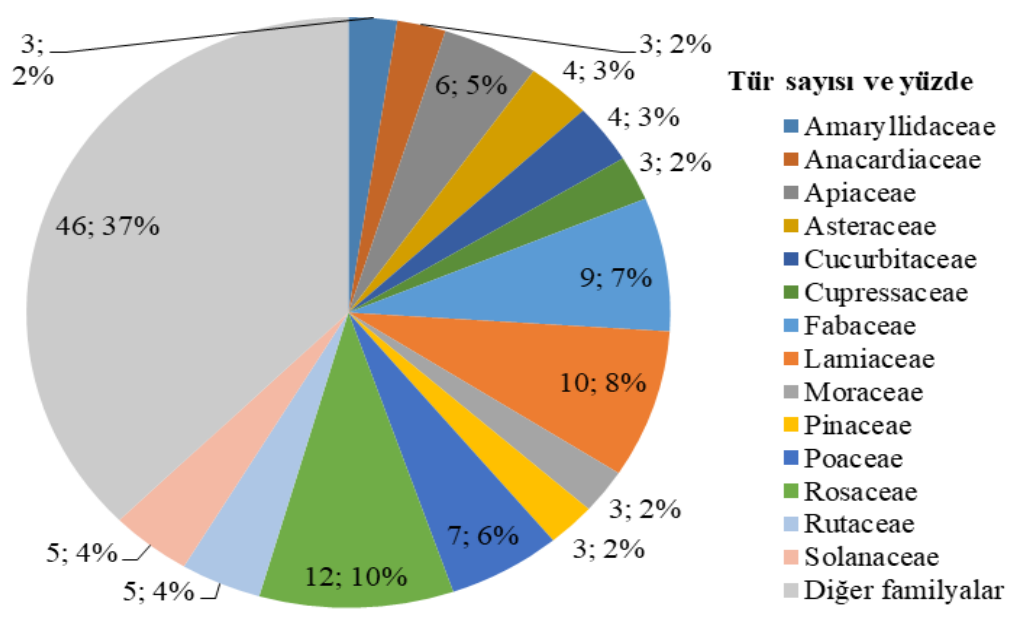

Şekil 4. Toplam tür sayısına göre familyalar

Bölgede 123 bitki türü arasından Lamiaceae familyasına ait olan Origanum onites L., 18 kiși tarafından kullanılarak en fazla kullanılan tür olmuştur (Şekil 5). Bölgede yapılan diğer çalışmalarda [15, 17-20] da aynı durumun görülmesi bu bitkinin bölgede geniş bir yayılışa sahip olduğunu gösterir.
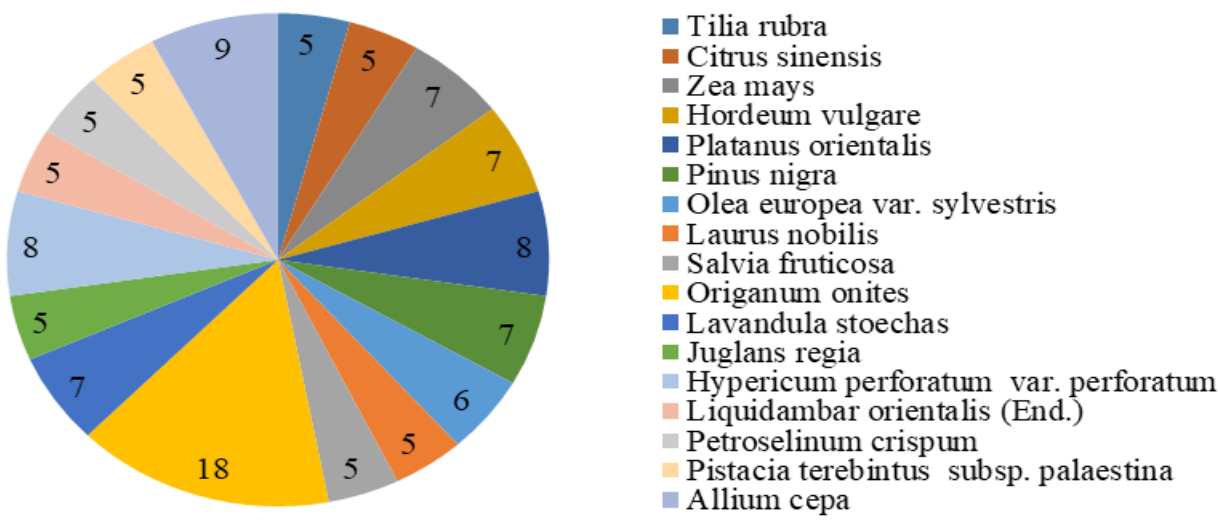

Şekil 5. Kullanım sayılarına göre bitki türleri

Kullanılan organların büyük çoğunluğunu \%24 (53 tür) oranla meyve oluşturmaktadır (Şekil 6). En fazla kullanılan organın meyve olması bölgenin meyve çeşitliliği bakımından zengin olduğunu düşündürtmektedir.

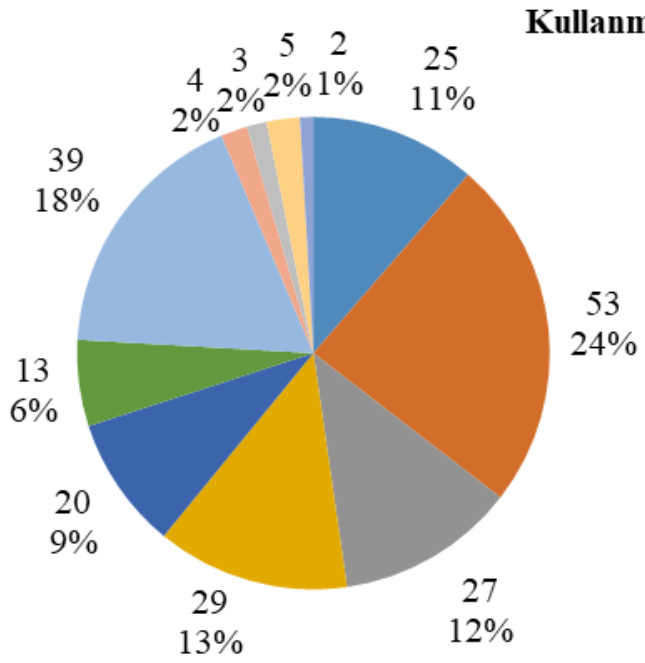

- Yaprak

Meyve

- Tohum

Gövde

- Dal

- Kök

- Topraküstï organlar

- Çiçek

Meyve Sap1

Şekil 6. Kullanılan organların kullanım yüzdesi 
Olea europea L., Allium cepa L., Origanum onites L., Hypericum perforatum L., Lavandula stoechas L., gibi bazı türler Muğla ilinde yapılan diğer benzer çalışmalarda da aynı amaçla kullanıldığı gibi, farklı amaçla da kullanılabilmektedir [14-19, 25]. Bu da bize bu bitkilerin halk arasında hala yaygın olarak kullanıldığını göstermektedir.

Muğla ilinde yapılan etnobotanik çalışmalarında verilen bilgiler arasında bitkilerin kullanım şekilleri ve amaçları gibi faktörler arasında büyük benzerlik söz konusu iken bitkilerin yerel adları arasında farklılıklar da gözlenebilmektedir. Bu farklılığa bilgilerin nesilden nesile sözlü olarak aktarılması, kısmen ya da tamamen değişime açık olması, bölgeden bölgeye kullanıma eklemeler olması ve farklı kültürlerin etkisi neden olabilmektedir.

Geçmişte günümüze nazaran insanlar, bitkileri sadece tedavi amaçlı değil, eşya, boya, barınma, parfüm, esans, yapıştırıcı gibi birçok amaçla kullanmışlardır. Zaman içinde sözlü olarak aktarılan bu bilgilerden bazıları kaybolmuş, bazıları da insan ihtiyaçları değiştiği için terk edilmiştir. Var olan bu bilgilerin kaybolması aslında kültür mirası olan bu bilgilerin sonraki nesillere aktarılmasına engel olmaktadır. Bu mirası korumanın ve sonraki nesillere aktarılmasını sağlamanın bitkilerin korunmasını da arttıracağı düşünülebilir. Bu sayede zengin bir doğal çeşitliliğe ve çok sayıda endemik türe sahip ülkemizin de bitki mirasına daha fazla önem verilmesi sağlanabilir. Yapılan etnobotanik çalışmalar kültür mirasımızın korunmasına ve bitkilerin öneminin kavratılmasına sağladığı katkılardan dolayı önemli çalışmalardır.

Ula ilçesinde yapılan bu etnobotanik çalışması da kültür mirasımızın korunmasına ve bitkilerin öneminin kavratılmasına sağladığı katkılardan dolayı önemlidir.

Muğla ili ve çevresi geçmişten günümüze sayısız medeniyete ev sahipliği yapmış, bu tarihi birikimden izler taşıyan ayrıca sahip olduğu bitki örtüsü bakımından da doğal bir zenginliğe sahiptir. Yörede yapılacak ya da yapılmış olan etnobotanik çalışmalar bize bitki kullanımının insan hayatına etkisini ve katkısını göstermesi bakımından önem taşımaktadır. Bu çalışmalar tamamlandığında kültürel mirasın kalıcı olması sağlanmış, bitkilerin önemi kavranmış, bitkilerin sayısız kullanım şekli öğrenilmiş ve sonraki nesillere aktarılması sağlanmış olacaktır. Bizim çalışmamızın da bu amaç doğrultusunda bir katkı da bulunacağını düşünmekteyiz.

\section{Teşekkür}

Çalışmamıza verdiği katkılardan dolayı sayın hocamız Prof. Dr. Güven Görk’e teşekkür ederiz.

\section{Kaynaklar}

[[1] Işı, S., Gönüz, A., Arslan, Ü. ve Öztürk, M. (1995). Afyon (Türkiye) İlindeki Bazı Türlerin Etnobotanik Özellikleri, Ot Sistematik Dergisi, 2(1): 161-166

[2] Baytop, T. (1984). Türkiye'de Bitkilerle Tedavi (Geçmişte ve Bugün), İstanbul Üniversitesi Yayınları, İstanbul, $480 \mathrm{~s}$.

[3] Öztürk, M. ve Özçelik, H. (1991). Doğu Anadolu'nun Faydalı Bitkileri (Useful Plants of East Anatolia), Semih Ofset ve Matb., Ankara.

[4] Bayram, E., Kırıc1, S., Tansı, S., Yılmaz, G., Arabacı, O., Kızıl S ve Telci D. (2010). Tibbi ve Aromatik Bitkiler Üretiminin Arttırılması Olanakları. Türkiye Ziraat Mühendisliği VII. Teknik Kongresi Bildiriler Kitabl, 11 - 15 Ocak, ANKARA, 437-456.

[5] Sayar, A., Öztürk, M., Güvensen, A. ve Özdemir, F. (1995). Muğla (Türkiye) İlindeki Bazı Türlerin Etnobotanik Özellikleri, Ot Sistematik Botanik Dergisi,2,(1):151-160.

[6] Davis, P.H.,(1965-1988), Flora of Turkey and the East Aegean Islands. I-X. Edinburg Univ. Pres, Edinburg.

[7] Yıldırımlı, Ş. (2004). Etnobotanik ve Türk Etnobotaniği, İnsan Bilimleri için Kaynak Arastırmaları Dergisi, 17: 167- 174.

[8] Sağıroğlu, M., Arslantürk, A., Akdemir, Z.K., Turna, M. (2012). An ethnobotanical survey from Hayrat (Trabzon) and Kalkandere (Rize/Turkey). Biological Diversity and Conservation, 5(1), 31-43.

[9] Polat, R., Satıl, F., Çakılcıŏlu, U. (2011). Medicinal plants and their use properties of sold in herbal market in Bingöl (Turkey) district. Biodicon, 4(3):25-35.

[10] Polat, R., Çakılcığlu, U., Ulusan, M. D., Gür, F., Türkmen, Z. (2015). Investigations of ethnobotanical aspect of wild plants sold in Espiye (Giresun/Turkey) local markets. Biological Diversity and Conservation, 8(3), 114-119.

[11] Kökçü, B., Esen, O., Uysal, İ. (2015). Medicinal plants sold in Çanakkale/Turkey city center herbalists. Biological Diversity and Conservation, 8(3), 80-91.

[12] Korkmaz, M., Karakurt, E. (2015). An ethnobotanical investigation to determine plants used as folk medicine in Kelkit (Gümüşhane/Turkey) district. Biological Diversity and Conservation, 8(3), 290-303.

[13] Kayabaşı, N. P., Tümen, G., Polat, R., Okulu, G. M. Y., Genç, B. (2016). Ethnobotanical studies on useful plants in Manyas (Balıkesir/Turkey) region. Biological Diversity and Conservation, 9(3), 58-63.

[14] Ertuğ, F. (2004). Wild edible plants of the Bodrum Area (Muğla, Turkey), Turkish Journal of Botany, 28(12):161 174 .

[15] Tuzlacı, E. (2005). Bodrum' da Bitkiler ve Yasam, Nobel Yayın ve Dağıtım, İstanbul, 253 s.

[16] Tuzlacı, E. (2002). Datça Yarımadası (Muğla) Florası ve Bu Yörede Halkın Yararlandığı Bitkiler, 14. Bitkisel İlaç Hammaddeleri Toplantısı, Bildiriler, Eskişehir. 
[17] Tuzlacı, E. (2002). Baba Dağı florası ve Fethiye Yöresinde Halkın Yararlandığı Bitkiler Hakkında Yapılan Ön Araştırma, 14. Bitkisel ilaç Hammaddeleri Toplantısı, Bildiriler, Eskişehir.

[18] Gurdal, B. ve Kultur, S. (2013). An ethnobotanical study of medicinal plants in Marmaris (Mugla, Turkey). Journal of Etnopharmacology, vol.146, pp.113-126.

[19] Ceylan, O. (2017). Muğla İlinde Halkın Tedavi Amaçlı Kullandığı Bitkiler, Ot Sistematik Botanik Dergisi, 24, $1, \quad 89-107$

[20] Öztürk, M., Seçmen, Ö., Gemici, Y. ve Görk, G. (1990). Ege Bölgesi Bitki Örtüsü, Sentez Limited, 175 s., İzmir.

[21] Kalças, E., L. (1974). Food From The Fields, Edible Wild Plants Of Aegean Turkey, Bilgehan Matbaas1 Bornova, İzmir, $146 \mathrm{~s}$.

[22] Baytop, T. (1994). Türkçe Bitki Adları Sözlüğü, Türk Dil Kurumu Yayınları, Ankara, 578 s.

[23] Seçmen, Ö., Gemici, Y., Görk, G., Bekat, L. ve Leblebici, E. (2004). Tohumlu Bitkiler Sistematiği, 8. Baskı, Ege Üniversitesi Fen Fakültesi Kitaplar Serisi No:116, İzmir, 386 s.

[24] Güner, A., Aslan, S., Ekim, T., Vural, M. ve Babaç, M.T. (2012). Türkiye Bitkileri Listesi (Damarlı Bitkiler), Nezahat Gökyiğit Botanik Bahçesi Yayınları Flora Dizisi 1, İstanbul.1290s.

[25] Akan.H.,Öz.Aydın.,Pekmez.,H. (2018). Ortaca (Muğla) Yöresinde Halk Arasında Kullanılan Bazı Bitkiler, Türk Tarım - Gıda Bilim ve Teknoloji Dergisi, 6(9): 1168-1174, 2018 